\title{
Proposal of an educational technology approach for a web system construction. Application case: teaching about the Fungi kingdom
}

\section{Propuesta de un enfoque de tecnología educativa para la construcción de un sistema web. Caso de aplicación: enseñanza del reino Fungi}

\author{
Daniel Benito Moran \\ Anabelem Soberanes Martín \\ Traducción: Mónica Itzel López Cortés
}

\begin{abstract}
Educational technology, as it is nowadays understood, is a relatively new concept. Traditionally, it was understood as the use of audiovisual materials in the classroom; however, this concept has been left behind to be considered a fundamental part of educational processes, taking into account multiple disciplines. This research links theoretical foundations with the development of a web system considering pedagogical aspects for the generation of educational technology; this is done in three stages: (1) seeking educational foundation and its adaptation to technology, (2) the applicability of these to the concept of usability and (3) the development of the system web. The results obtained were favorable; the SUS (Scale Usability System) tool determined a usability level of 91.38. In this sense, creating a system that managed information about the Fungi kingdom considers the incorporation of pedagogical and technological techniques during the elaboration process. Considering the characteristics of the end-user will help the teaching-learning process and, thus, keep the interest from the user to continue using the generated instrument.
\end{abstract}

Keywords: educational software engineering, educational technology, mycology, usability.

\section{RESUMEN}

La tecnología educativa, como se entiende hoy en día, es un concepto relativamente nuevo, tradicionalmente era entendida como el uso de materiales audiovisuales en el aula, sin embargo, este concepto ha quedado atrás para ser considerada una parte fundamental en los procesos educativos, que toma en cuenta múltiples disciplinas para tener lugar. La presente investigación vincula fundamentación teórica con el desarrollo de un sistema web considerando aspectos pedagógicos para la generación de tecnología educativa; esta se realiza en tres etapas: (1) la búsqueda de bases educativas y su adecuación a la tecnología, (2) la aplicabilidad de estas al concepto de usabilidad y (3) el desarrollo del sistema web. Los resultados obtenidos fueron favorables, la herramienta SUS (Scale Usability System) determinó un nivel de usabilidad del 91.38. En este sentido, la creación de un sistema que gestione información sobre el reino Fungi considerando la incorporación de técnicas pedagógicas y tecnológicas durante el proceso de elaboración, con el propósito de tomar en cuenta las características del usuario final, ayudará al proceso de enseñanza-aprendizaje, y con ello, a mantener el interés por parte del usuario para seguir utilizando el instrumento generado.

Palabras clave: ingeniería de software educativo, tecnología educativa, micología, usabilidad. 


\section{INTRODUCTION}

This work is derived from a research project entitled "Desarrollo de un sistema web desde el enfoque de tecnología educativa para difundir información sobre el reino fungi". Society is in constant change, which is why it produces a large amount of information about a large variety of topics, each one from different perspectives, this information requires tools that can systematize it and bring it closer to users, who transform it into knowledge.

This process is carried out within the Knowledge Society, considered as a model of social organization, in which each individual has the opportunity to generate new knowledge; it will only be achieved through its renewal and dissemination, helping individuals to adapt to this changing and unstable environment, and enables them to obtain a future vision. In this way, the search of the society of knowledge has led to scientific communities' project strategies to socialize or "popularize" the knowledge gained from their research to the different actors in society to achieve its understanding and assimilation. This has been called the social appropriation of knowledge (Marín, 2012).

In this context, the social appropriation of knowledge is a matter of recent concern for scientific communities, governments and the media, which has been assumed as a social commitment of the community (Marín, 2012). David and Foray (2002) mention that there is a new agent in the diffusion of knowledge, communities of knowledge, which are defined as networks of individuals whose main objective is the production and diffusion of new knowledge, elaborated through the collective construction of knowledge, bringing together people belonging to different entities, but specialists in the same subject. This construction is made from the personal apprehension of the concepts and ideas found in the theory, which has been carried out by other people, so that, in principle, there is a collective construction, which is enriched by the accessibility of information through the media and digital mediations (Pinto, 2013).

Therefore, the appropriation of knowledge from the perspective of the Knowledge Society facilitates the spread of this, both in scientific and educational fields,

Daniel Benito Moran. Universidad Autónoma del Estado de México. Es maestro en Ciencias de la Computación y actualmente cursa el doctorado en Ciencias de la Computación con especialidad en Tecnología Educativa por la Universidad Autónoma del Estado de México, en el Centro Universitario Valle de Chalco. Participante del XVIII y XIX Verano de la Investigación Científica y Tecnológica del Pacífico. Docente a nivel medio superior y superior. Cuenta con diplomados en habilidades tecnopedagógicas. Correo electrónico: dbenitom883@alumno.uaemex.mx. ID: https://orcid.org/0000-0002-4015-8342.

Anabelem Soberanes Martín. Universidad Autónoma del Estado de México. Es profesora de tiempo completo del Centro Universitario Valle de Chalco de la Universidad Autónoma del Estado de México. Es doctora en Ciencias de la Educación, certificada como Coordinadora de Actividad a Distancia (San Diego Global Knowledge University) e Instructora de Cursos Presenciales (Conocer). Tiene el reconocimiento al perfil Prodep y fue integrante del Sistema Nacional de Investigadores (2013-2020). Integrante del Cuerpo Académico Cómputo Aplicado y docente de la licenciatura, maestría y doctorado. Su línea de investigación es tecnología educativa. Correo electrónico: asoberanesm@uaemex.mx. ID: https://orcid.org/0000-0002-1101-8279. 
benefiting each other, which is called democratization of knowledge, understood by various authors, including Marotias (2015) and Alterius (2016) as the liberation of knowledge or immediate access to educational, academic, scientific material in its digital form and without restrictions, through Internet. García, Gargallo, García \& Sánchez (2012) mention the relevance of the Internet in the daily life of today's society as a space for access to information, being timeless and lacking a defined space it is possible to obtain information on the same topic from different perspectives, without excluding some problems that it faces as information without validity or lack of systematization of this.

In consequence, the dissemination of knowledge at the present time must take into account the use of technology to reach its aim. One element to be considered are the Information Systems (IS) and a transformation of them, called knowledge system, which is an organized structure and dynamic process; reinforced by a group of relationships that connect the content of knowledge to its value (utility); enhanced by a set of iterative processes that allow evolution, revision, adaptation and advancement; subject to the criteria of relevance, reliability and quality (MIT, 2017). The University of Granada (2017) defines characteristics of this type of system, they work through two operational parts that complement each other: the creation of the knowledge base through associated words and the query that manages it. There must be feedback, in such a way that the knowledge base itself obtains a higher classification. For each output, the system must provide objective knowledge made up of: research topics, graphic representations of knowledge networks, maps or strategic diagrams, among others.

In this way, web systems, as knowledge systems for the acquisition of knowledge, have emerged as useful elements in the teaching-learning process, allowing interaction between the user who receives the knowledge and the one who provides it, in an exchange of information through an electronic device such as cell phone, computer, among others.

Whereby, the traditional educational context has changed; Mestre, Fonseca and Valdés (2007) mention that currently learning environments are not only limited to physical space, they also include spaces that encourage the acquisition and appropriation of knowledge. In accordance with the above, since the emergence of virtual teaching environments, a way has been sought to link all computer aspects in one place.

In recent years, the most recurrent way of representing a virtual environment is through a web system, defined as a tool that raises and uses the client-server architecture, in which the client or user, using any web browser, access the application through the address where the respective web server is located; the access is either the Internet or an Intranet (Aguilar \& Dávila, 2013). These web systems are useful in the dissemination of information, in this particular case study, of biodiversity. Some authors such as Aguirre-Acosta, Ulloa, Aguilar, Cifuentes and Valenzuela 
(2014) among others argue that Mexico is a country that is home to a wide variety of Fungi kingdom species that possess healing properties and power, and therefore constitute a critical part of the traditional diet of the area. Guzmán (1995) mentions that knowledge about fungi were acquired by experience of the people and have traditionally been transmitted orally for generations, same as have been the source of information of the first investigations.

The present investigation takes this knowledge that has been dispersed and brings it together in web system, combining its construction by means of concepts, methods and techniques of technology and education to generate attention in the student; this research makes use of the concept of usability ${ }^{1}$ to achieve it. It is necessary to point out the viability of basing the term of usability through pedagogical theories, first, on the sociocultural theory of Lev Semionovich Vygotsky, and especially, his concept of a zone of proximal learning, which expresses in a concentrated way a psychological vision of man. It can be interpreted as a system where the subject that learns, the symbolic system that is learned and the subject that teaches are identified, as elements in a space of relationship. It is not enough to understand as a potential default in one of its components, but as an emerging space relationship that develops itself in its own existence (Corral, 2001); then in constructivism that raises the need to provide the student with the required means (generation of scaffolds or also called cognitive bridges) that allow them to structure their own procedures for solving problems, which entails a renewal of ideas in each situation and allows them to learn continuously, this supported by the contributions of Jean William Fritz Piaget and Lev Semiónovich Vygotski (Ortiz, 2015); finally, connectivism presenting a model that acknowledges the tectonic shifts in society where the learning is no longer an internal and individualistic activity, therefore, it does reside outside of ourselves (within an organization or a database) (Siemens, cited by Bates, 2019).

At the same time research were developed on pedagogical theories, inclusion of ICT in education was highlighted; this phenomenon was named by Skinner technification of teaching, mentioned above, same that evolved to Educational Technology (TE), this concept has several meanings, but for the purposes of this investigation, it was considered as a systematic way of designing, implementing and evaluate the set of teaching and learning processes, taking into account both technical and human resources and the interactions between them, in order to obtain a more effective education (UNESCO, 1984).

Finally, the web systems are the main source of inquiry in education, being the primary technology resource today; this information is not frequently converted into knowledge, so that the purpose of creating this type of system is not reached, because

1 "Measure in which a product can be used by certain users to achieve specific objectives with effectiveness, efficiency and satisfaction, in a given context of use" (International Organization for Standardization [ISO], cited by Dimuro, 2014, p. 6). 
of its construction it is made from an engineering point of view; likewise, from the perspective of ET, the incorporation of communication resources and materials is essential to generate better results in the teaching-learning process, it requires the implementation of methods and techniques focused on the characteristics of the user, which facilitate achieve meaningful learning. The process is complicated as there is no consolidation of its own terminology, which is why it is feasible to base these computer concepts on pedagogical knowledge, as it was done in this section.

\section{Methodology}

An applied investigation was performed, it took as a basis, social issues or from the productive sector in order to produce applicable knowledge, based on technological findings and thus putting together theory and product (Lozada, 2014). The initial investigative process consisted of the search for pedagogical theories applied to technology; after the application of these to the concept of usability, it means to consider the characteristics and needs of the user to develop the system. Subsequently, the development of the system as a final product, which was carried out using the educational software development methodology, proposed by Galvis (1997), which consists of five stages: analysis, the requirements were met in order to solve the problem in question; design, tools (UML, entity-relationship, flow diagrams, among others) were used to identify the components to be implemented; development, based on the previous point began coding; pilot tests; and finally, field tests.

Considering the analysis generated from the specifications given by the user, the design of the system is made, in addition to elements such as the database and schematization of the communication between the client and the server, which were needed during the construction and specification. To develop the design, aspects of usability were taken into account as a metric that relies on the development of educational technological systems.

At the beginning, the hierarchy of the text was notorious for the user, this means that the distinction of titles, subtitles, relevant notes, paragraphs, among other elements is recommended; in addition, the structure of the website is consistent and so the distribution of information also is, likewise, it is classified with the technique of the inverted pyramid, in which you have the most important and concise text in first level, where you answer what information is presented; the second level is the body, in which the reason of this information is developed, it conducts the anchoring of the user's attention; finally, the third level is intended to show those writings, which are equally essential, but to the very being extensive, is revealed at this level in order not to saturate at first instance (Dimuro, 2014; Ortiz, 2012).

Moreover, navigation is intuitive for the user, it looks like they do not need to learn technical and technological issues for management or navigability in the sys- 
tem, therefore, the map of the site will be clear in its composition. In addition to a responsive design, it will make the user feel comfortable regardless of the device or place where they are viewing it.

Additionally, the technique of conventions is used, Dimuro (2014) defines it as several unwritten standards, acquired through daily use, identified by most of the people who use a website and with this they usually understand and interpret them in the same way; this means that it is not necessary to re-educate the user, since they do not have to learn new symbology or actions within the system, but they are already familiar with the existing ones. Otherwise, from the technical point of view, Figure 1 shows the client-server communication.

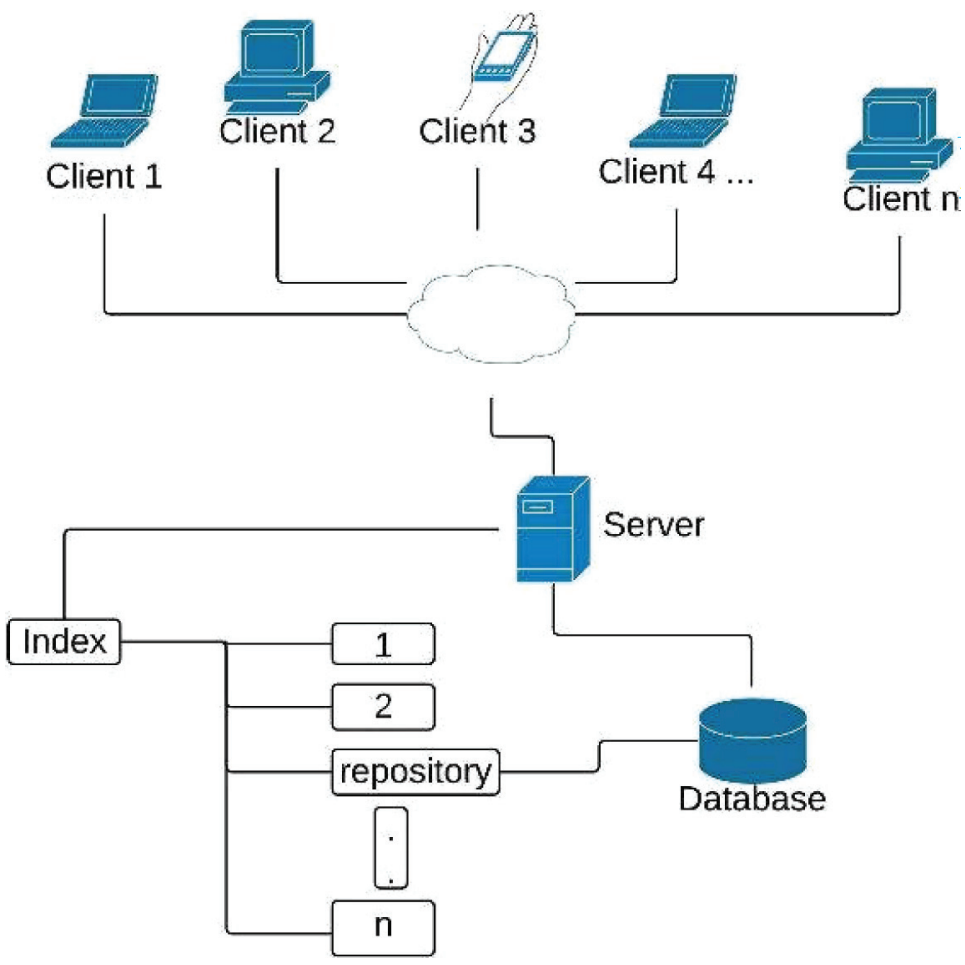

Figure 1. Client-server communication diagram. Source: Own elaboration based on Benito (2019, p. 41).

Similarly, in Figure 2, the process carried out by the user to perform a request to the repository is presented, and this in turn executes a search statement towards the database with the parameters provided, finally, showing the results on screen.

In addition to the techniques of modeling mentioned, and in order to facilitate the construction of this system that not only is represented in structures, code and other merely things engineering, in particular, use is made of mockups to help generate a link between the instructional design and the developer (Cao, Wang \& Zheng, 2012). Also, the difficulty by developers to meet the educational specifications of it 


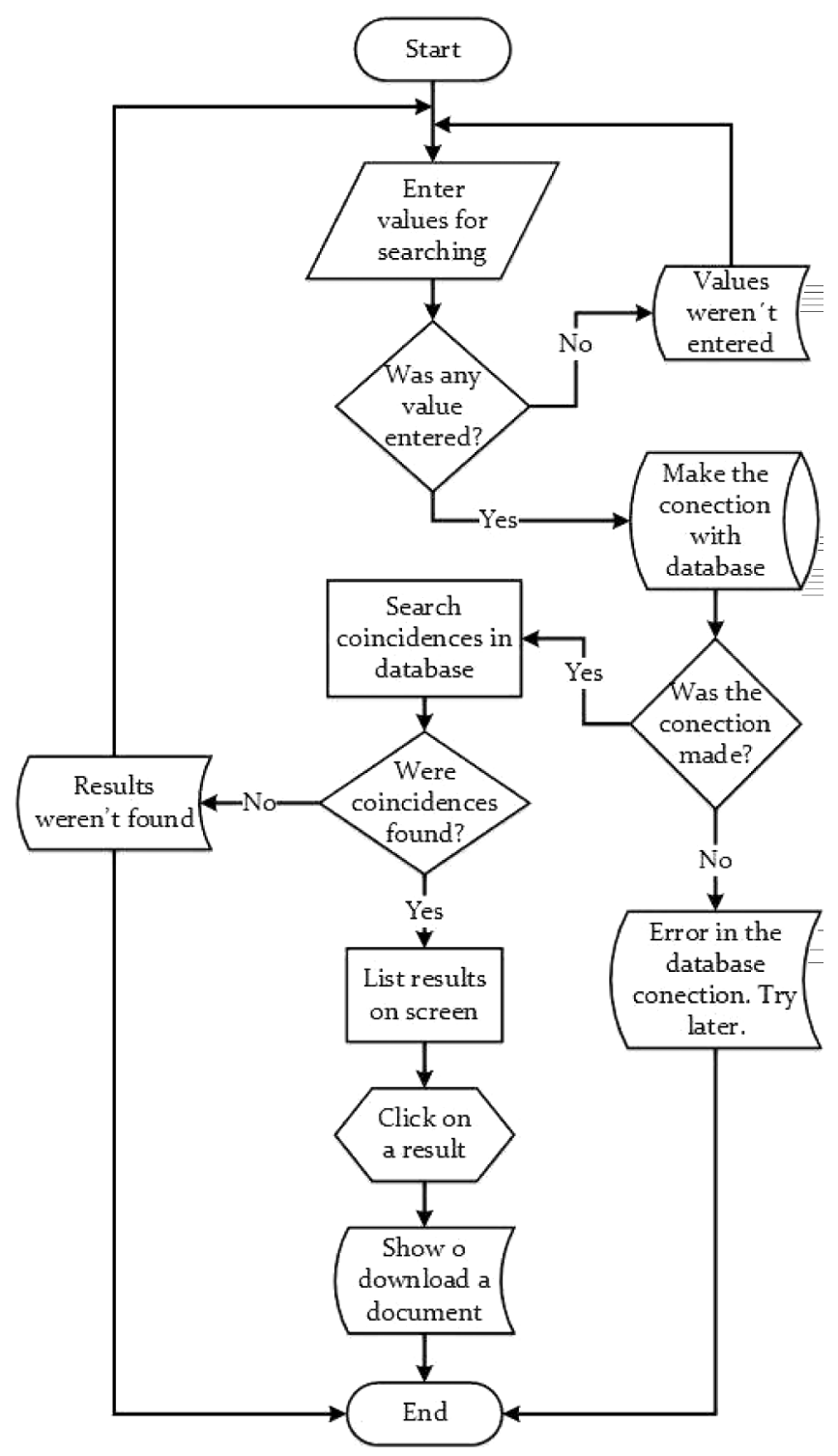

Figure 2. Repository flow diagram.

Source: Own elaboration based on Benito (2019, p. 42).

are generally presented during the technical development, in this case are ironed with mockups, that frequently decipher visually, the educational techniques that they seek to implement. That is why they are developed at this stage, they show the consistency in the structure of the pages, therefore, the website will have the same distribution.

Dimuro (2014) mentions that the distribution proposed (see Figure 3) is suitable for the insertion of components of a website, in order to not saturate the user with too much information; the author points out the menu as one of the important aspects in this way of arrangement, that place is chosen since people spend $69 \%$ of the time focusing their eyes on the left side of the page (this is due to the way in 
which writing is performed from left to right), the way that it applies this feature in the design is conserved in every page of the site, in order to maintain consistency in navigating by the user; consequently, the attraction starts with the menu to end the content. In the same way, in the mobile version, the balance in the distribution of the screen as in the desktop is preserved, therefore, there will only be respective changes related to the adaptation in a cell phone or similar device.

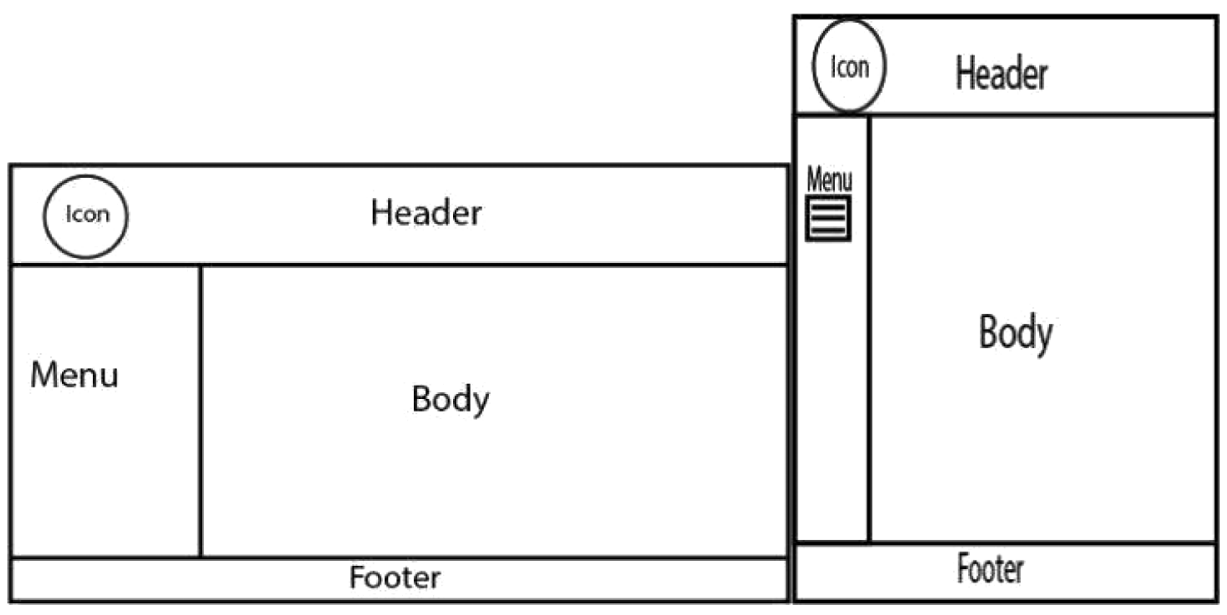

Figure 3. Distribution of content. Source: Own elaboration based on Benito (2019, pp. 44, 47).

Likewise, to continue building the mentioned link, the use of underestimated diagrams is proposed because they are considered not very relevant during the implementation; however, in this research they were very useful throughout the coding of the system. As an example, the site map is presented (see Figure 4), which is made up of a home page, four main categories and 34 subcategories that contain various sections referring to these topics.

From the design, the next stage is developed, in which the components of the web system are implemented and explained. It was developed using various standards. In the first instance, the menu and its options were implemented on the left side; it should be noted that in this characteristic the segments of the page layout are not mixed (see Figure 5), in order to use the time mostly where the user is focusing, deriving in a noninvasive menu on the information you want to present.

On the other hand, if there is a problem that the menu is displayed in this way, the option of being collapsed and showing its sections in a floating way is added; and in this regard, two features take advantage: consider the opinion of the user, making the experience personal use, and use their targeting as profit, generating a wider range of care information and minimizing the area to make it very relevant in that moment.

In the same way and using pedagogical foundations of the theories of Jean Piaget and Lev Vygotsky (in particular the concepts of cognitive bridges or scaffolds and 


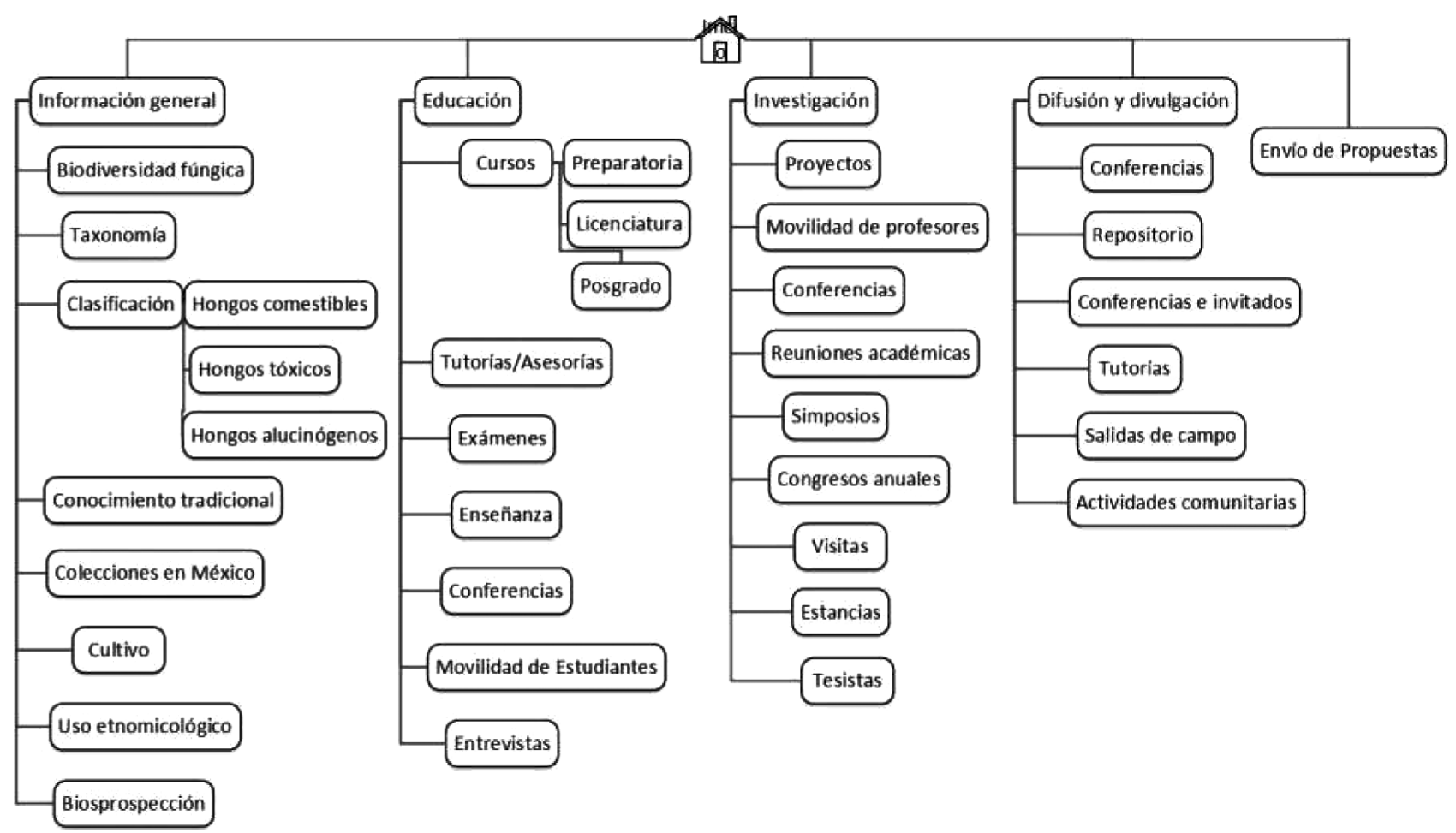

Figure 4. Site map (in Spanish language).

Source: Benito (2019, p. 51).

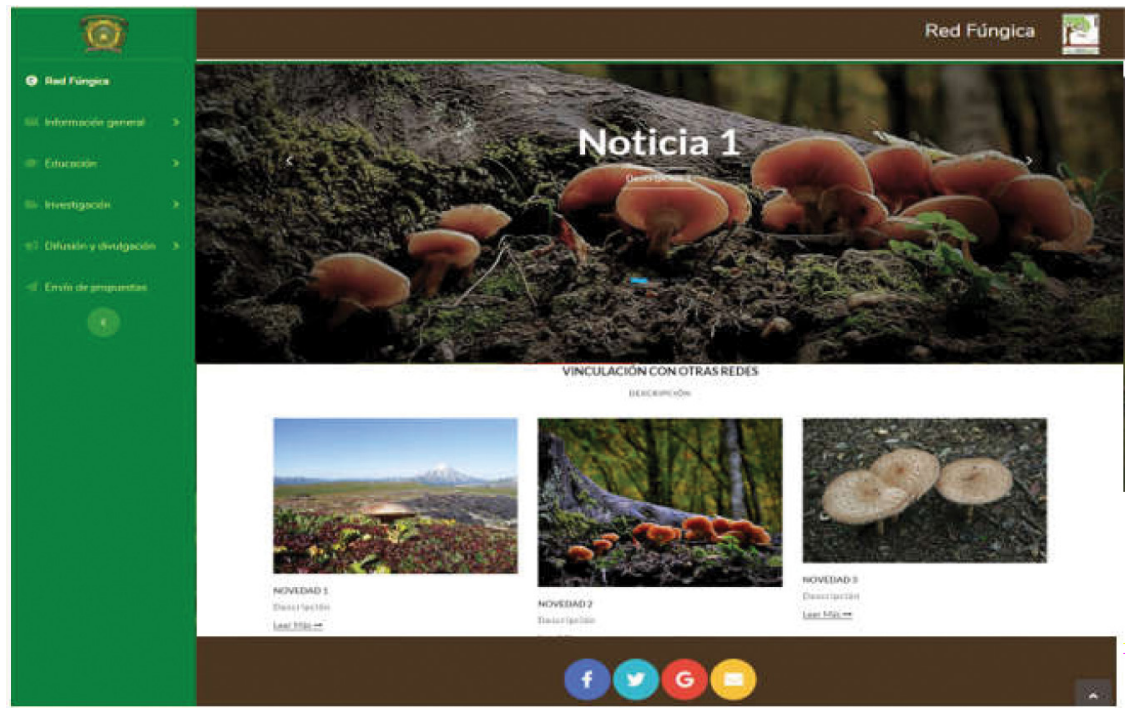

Figure 5. Home web page (in Spanish language).

Source: Benito (2019, p. 52).

zone of proximal development), the repository section is generated, which presents new forms of search considering elements familiar to the user and making use of them as links between the base knowledge and the new one; this section has the following characteristics: 
- A dynamic search engine is presented that finds matches in real time, based on the criteria provided (see Figure 6).

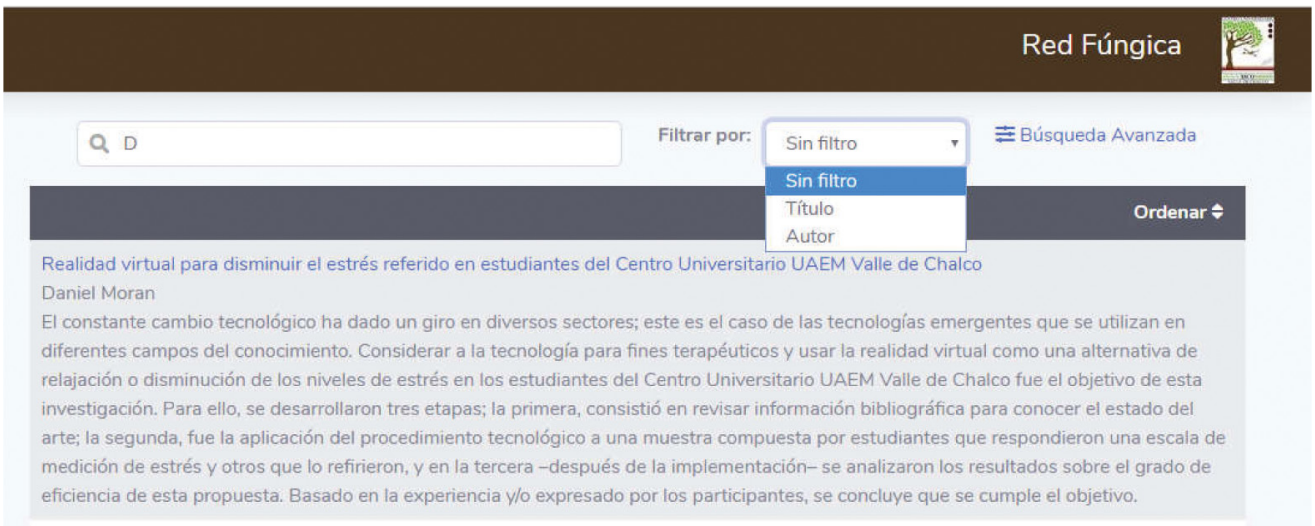

Figure 6. Search in the repository (in Spanish language).

Source: Benito (2019, p. 55).

- The filters, implemented in the search, use understandable terms to the user, they can fill several fields if they require a more accurate scan, or just a space for matches with the data they remember or want to search (see Figure 7).

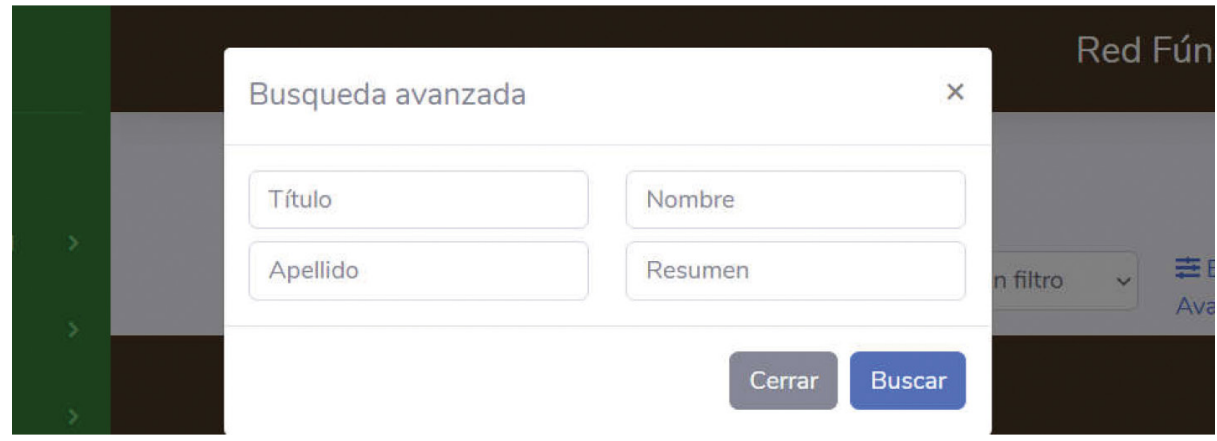

Figure 7. Searching (in Spanish language).

Source: Benito (2019, p. 56).

Finally, tests were applied with which the operation of the system were checktestes, these were structural, functional, nonfunctional and regression. 35 of each type were applied (except for the last ones); in the first instance, the functional inquired into the conduct expected to be made in the system, 27 found errors in managing users and files; on the other hand, broken links were detected, they went to the wrong place; the following eight were control; consequently, the non-functional ones looked for the way in which the system is executed. This type of tests are perfectible, so after 35 the user experience continues to improve by optimizing the code and redesigning the elements that make up the system. In the same way, the structural ones contem- 
plate the possible flow to be followed by the user, in this sense, 35 people were taken at random to carry out their own flows within the system, and as a result, 19 found failures in the steps they executed, for example, errors when attaching files, necessary empty fields, missing connection to the database, among others, which were corrected; the remaining 16 did not mention failures; finally, regression tests, which are aimed at examining corrected errors, were performed throughout the implementation and testing process.

\section{RESULTS}

The level of usability was determined by means of the System Usability Scale or SUS (Brooke, 1996), which uses items with responses on the Likert scale, with numbers from 1 to 5 , where 1 totally agrees and 5 totally disagrees. In this regard, to determine the level of usability of the system, the author details that a calculation takes the rating assigned by users in the first instance, it subtracts one to the odd items and subsequently five to pair items; finally, the result is multiplied by 2.5. In mathematical terms the following formula applies where takes the values of the odd questions and assigned values pairs items. The instrument was applied to 20 users (see Table 1), after an analysis overall results, the following was determined:

- In connection with the statement "I think that I would like to use this system frequently", whereas $100 \%$ of the responses, $60 \%$ mention they completely agree, $30 \%$ agree and $10 \%$ has a neutral opinion.

- Regarding the statement "I found the system unnecessarily complex", 30\% of the total disagreed and the remaining $70 \%$ completely disagreed.

- In terms of the statement "I thought the system was easy to use", 75\% reflected fully agree, while 25\% agree.

- Given the statement "I think that I would need the support of a technical person to be able to use this system", $25 \%$ of the participants claim to disagree, while $75 \%$ strongly disagree.

- In the case of the statement "I found the various functions in this system were well integrated", $60 \%$ of the total responded fully in agreement, 35\% in agreement and $5 \%$ in a neutral position.

- Regarding the item "I thought there was too much inconsistency in this system", $15 \%$ remains neutral, $25 \%$ disagree and $60 \%$ completely disagree.

- In terms of the sentence "I would imagine that most people would learn to use this system very quickly", 75\% mentioned being in complete agreement, $20 \%$ in agreement and 5\% were neutral.

- Given the statement "I found the system very cumbersome to use", 20\% affirm to agree while $80 \%$ totally disagree. 
Table 1. Answers to the SUS questions.

\begin{tabular}{ccccccccccc}
\hline & \multicolumn{1}{c}{ Q } & \multicolumn{1}{c}{ Question } & & & \\
\cline { 2 - 9 } User & I & II & III & IV & V & VI & VII & VIII & IX & X \\
\hline 1 & 5 & 2 & 5 & 1 & 4 & 1 & 5 & 1 & 5 & 1 \\
\hline 2 & 4 & 1 & 4 & 2 & 4 & 2 & 5 & 1 & 5 & 2 \\
\hline 3 & 3 & 1 & 4 & 2 & 5 & 2 & 5 & 1 & 4 & 2 \\
\hline 4 & 5 & 1 & 5 & 1 & 5 & 3 & 5 & 1 & 4 & 1 \\
\hline 5 & 5 & 1 & 5 & 1 & 5 & 2 & 5 & 1 & 5 & 2 \\
\hline 6 & 4 & 2 & 5 & 1 & 5 & 1 & 5 & 2 & 4 & 3 \\
\hline 7 & 5 & 1 & 5 & 1 & 4 & 1 & 5 & 1 & 5 & 1 \\
\hline 8 & 4 & 1 & 5 & 1 & 4 & 1 & 5 & 2 & 4 & 1 \\
\hline 9 & 3 & 2 & 5 & 1 & 5 & 1 & 5 & 1 & 5 & 1 \\
\hline 10 & 5 & 1 & 5 & 1 & 3 & 1 & 5 & 2 & 5 & 1 \\
\hline 11 & 5 & 2 & 5 & 1 & 4 & 1 & 5 & 1 & 5 & 1 \\
\hline 12 & 5 & 1 & 5 & 2 & 4 & 1 & 4 & 2 & 5 & 1 \\
\hline 13 & 4 & 1 & 5 & 1 & 5 & 1 & 5 & 1 & 5 & 1 \\
\hline 14 & 4 & 2 & 5 & 1 & 4 & 1 & 5 & 1 & 5 & 1 \\
\hline 15 & 5 & 1 & 4 & 1 & 5 & 1 & 4 & 1 & 5 & 1 \\
\hline 16 & 4 & 2 & 4 & 1 & 5 & 1 & 5 & 1 & 5 & 3 \\
\hline 17 & 5 & 1 & 3 & 1 & 5 & 2 & 4 & 1 & 5 & 1 \\
\hline 18 & 5 & 1 & 5 & 2 & 5 & 3 & 3 & 1 & 5 & 1 \\
\hline 19 & 5 & 1 & 5 & 2 & 5 & 3 & 5 & 1 & 5 & 1 \\
\hline 20 & 5 & 1 & 5 & 1 & 5 & 2 & 4 & 1 & 5 & 2 \\
\hline
\end{tabular}

Source: Benito (2019, p. 92).

- In reference to the statement "I felt very confident using the system", $80 \%$ totally agree, while $20 \%$ said they agree.

- Finally, about the assertion "I needed to learn a lot of things before I could get going with this system", 10\% reflected a neutral feeling, 20\% disagreed and $70 \%$ said they completely disagreed.

Based on the values presented in Table 1, the first part of the process is calculated and the results (see Table 2) are obtained from:

$$
\begin{array}{ll}
\mathrm{I}=\left(i_{1}-1\right) & \mathrm{II}=\left(5-p_{2}\right) \\
\mathrm{III}=\left(i_{3}-1\right) & \mathrm{IV}=\left(5-p_{4}\right) \\
\mathrm{V}=\left(i_{5}-1\right) & \mathrm{VI}=\left(5-p_{0}\right) \\
\mathrm{VII}=\left(i_{7}-1\right) & \mathrm{VIII}=\left(5-p_{8}\right) \\
\mathrm{IX}=\left(i_{9}-1\right) & \mathrm{X}=\left(5-p_{10}\right)
\end{array}
$$


Table 2. Application of the formula for each item.

\begin{tabular}{|c|c|c|c|c|c|c|c|c|c|c|}
\hline \multirow[b]{2}{*}{ User } & \multicolumn{10}{|c|}{ Question } \\
\hline & I & II & III & IV & V & VI & VII & VIII & IX & $\mathrm{X}$ \\
\hline 1 & 4 & 3 & 4 & 4 & 3 & 4 & 4 & 4 & 4 & 4 \\
\hline 2 & 3 & 4 & 3 & 3 & 3 & 3 & 4 & 4 & 4 & 3 \\
\hline 3 & 2 & 4 & 3 & 3 & 4 & 3 & 4 & 4 & 3 & 3 \\
\hline 4 & 4 & 4 & 4 & 4 & 4 & 2 & 4 & 4 & 3 & 4 \\
\hline 5 & 4 & 4 & 4 & 4 & 4 & 3 & 4 & 4 & 4 & 3 \\
\hline 6 & 3 & 3 & 4 & 4 & 4 & 4 & 4 & 3 & 3 & 2 \\
\hline 7 & 4 & 4 & 4 & 4 & 3 & 4 & 4 & 4 & 4 & 4 \\
\hline 8 & 3 & 4 & 4 & 4 & 3 & 4 & 4 & 3 & 3 & 4 \\
\hline 9 & 2 & 3 & 4 & 4 & 4 & 4 & 4 & 4 & 4 & 4 \\
\hline 10 & 4 & 4 & 4 & 4 & 2 & 4 & 4 & 3 & 4 & 4 \\
\hline 11 & 4 & 3 & 4 & 4 & 3 & 4 & 4 & 4 & 4 & 4 \\
\hline 12 & 4 & 4 & 4 & 3 & 3 & 4 & 3 & 3 & 4 & 4 \\
\hline 13 & 3 & 4 & 4 & 4 & 4 & 4 & 4 & 4 & 4 & 4 \\
\hline 14 & 3 & 3 & 4 & 4 & 3 & 4 & 4 & 4 & 4 & 4 \\
\hline 15 & 4 & 4 & 3 & 4 & 4 & 4 & 3 & 4 & 4 & 4 \\
\hline 16 & 3 & 3 & 3 & 4 & 4 & 4 & 4 & 4 & 4 & 2 \\
\hline 17 & 4 & 4 & 2 & 4 & 4 & 3 & 3 & 4 & 4 & 4 \\
\hline 18 & 4 & 4 & 4 & 3 & 4 & 2 & 2 & 4 & 4 & 4 \\
\hline 19 & 4 & 4 & 4 & 3 & 4 & 2 & 4 & 4 & 4 & 4 \\
\hline 20 & 4 & 4 & 4 & 4 & 4 & 3 & 3 & 4 & 4 & 3 \\
\hline
\end{tabular}

Source: Benito (2019, p. 93).

Subsequently, the summation of all questions is carried out and the result is multiplied by 2.5; finally, an average of what is achieved by each user is made to obtain usability in a general way on the 20 people interviewed (see Table 3).

In correspondence with the results produced by the analysis of ITS and the evaluation scale established by the same instrument, specifying that from 68 will have a system with an acceptable level of usability and 100 an excellent level of usability (Brooke, 1996), it was determined that, with a 91.375, it is possible to say that what has been developed is correctly adapted to the characteristics of the end user. In the second instance, to obtain general opinions to be considered for later improvements or adjustments, a questionnaire was created with six open questions, which considered personalization, communication tools, presentation of the topics, among other issues. 
Table 3. Final implementation of the formula.

\begin{tabular}{|c|c|c|c|}
\hline User & $\Sigma(i-1)+\Sigma(5-p)$ & $(\Sigma(i-1)+\Sigma(5-p)) * 2.5$ & Average usability \\
\hline 1 & 38 & 95.0 & \multirow{20}{*}{91.38} \\
\hline 2 & 34 & 85.0 & \\
\hline 3 & 33 & 82.5 & \\
\hline 4 & 37 & 92.5 & \\
\hline 5 & 38 & 95.0 & \\
\hline 6 & 34 & 85.0 & \\
\hline 7 & 39 & 97.5 & \\
\hline 8 & 36 & 90.0 & \\
\hline 9 & 37 & 92.5 & \\
\hline 10 & 37 & 92.5 & \\
\hline 11 & 38 & 95.0 & \\
\hline 12 & 36 & 90.0 & \\
\hline 13 & 39 & 97.5 & \\
\hline 14 & 37 & 92.5 & \\
\hline 15 & 38 & 95.0 & \\
\hline 16 & 35 & 87.5 & \\
\hline 17 & 36 & 90.0 & \\
\hline 18 & 35 & 87.5 & \\
\hline 19 & 37 & 92.5 & \\
\hline 20 & 37 & 92.5 & \\
\hline
\end{tabular}

Source: Benito (2019, p. 94).

\section{Discussion}

After performing the procedures and stages of research mentioned, it was identified the need to combine educational theories and engineering processes for creating software for educational purposes to support the teaching-learning process. This conjunction is difficult for both, educators and technocrats, since each area uses its perspective with little regard for the other. In the absence of such separation, technology systems are constructed covering a need to automate the process, therefore to solution it tends to be insufficiently effective; in the same way, the development of teaching materials is restricted by not understanding the scope and limitations of a computer system, in other words, the lack of knowledge of both disciplines is combined.

This research brings together basic and essential foundations of both areas for the generation of the final product, based on the author's own knowledge and validations or approvals of experts, as well as, on the collection of opinions of the users 
to whom the system is directed; and these last ones generated positive judgements compared to other systems they have already used.

In this sense, by doing a review of some platforms and websites used for educational purposes, it is possible to identify some of the inconveniences they present, specifically restricted access to their information, poor administration of the courses, little or no interaction between participants, little planning of activities, as well as the lack of organization and selection of information; these problems generate loss of interest from the user, who tends to abandon the use of said systems. Therefore, this system seeks to democratize information, promoting interaction in users through discussion forums, the use of materials managed by tools that have been based on pedagogical theories that seek to influence the cognitive development of the student, and so on.

On the other hand, the employ of a usability instrument is relevant, since its implementation is not common during the design of a web system for educational purposes. The results show that it is feasible to track this study for the incorporation of other teaching techniques that satisfy end-users, considering that the processes used can be adapted together with various existing ones, looking for a specific job that meets educational or instructional design needs. However, it is also suggested to address various aspects, such as study methods, activities that impact similar work and actions to be carried out in the near future to improve this research, including the application of an educational software development methodology that is adapted to current conditions; consider a greater number of pedagogical elements in order to improve instructional design; take into account both the characteristics of the student and the teacher in order to offer a personalized experience for both; expand the population of users and the time of use of the system to compare the results of the evaluation instruments; form multidisciplinary work teams, with the purpose of covering the deficiencies expressed in this research by each area of knowledge; and finally, increase the number of applications of the work methodology used in various case studies to improve the process, and thus, the possible creation of a methodology focused on the creation of this type of solutions.

\section{Conclusion}

The objective of this research was to manage information about the Fungi kingdom with educational technology through a web system. First, an analysis was made, not only generating a list of requirements for the technological solution, but also educational needs. Afterwards, software modeling techniques were used in the design that helped the developer to visualize what was required to be generated; firstly, it is modeled with the help of mockups, which allowed us to concisely build a pleasant 
interface for the user, which was reflected in the usability assessment; secondly, the database was modeled using the UML standard.

Later, in the development phase, with the graphical representations used, the developer established things that in principle had been omitted by giving little relevance to important characteristics. The results showed a level of usability of the system of 91.38 , therefore, it is determined that matching components of teaching to engineering processes based on the parameters indicated by Brooke (1996) does have a positive impact on the user experience, and consequently, to the support of the teaching-learning process generated by the continuous use of the solution by the user, thus developing knowledge on a subject, in this way, both qualitative and quantitative aspects are solved.

\section{REFERENCES}

Aguilar, E., y Dávila, D. (2013). Análisis, diseño e implementación de la aplicación web para el manejo del distributivo de la Facultad de Ingeniería [Tesis de grado]. Universidad de Cuenca, Cuenca, Ecuador. Recuperada de: http://dspace.ucuenca.edu.ec/bitstream/123456789/4303/1/tesis.pdf.

Aguirre-Acosta, E., Ulloa, M., Aguilar, S., Cifuentes, J., y Valenzuela, R. (2014). Biodiversidad de hongos en México. Revista Mexicana de Biodiversidad, 85(2014), 76-81.

Alterius (2016). Del Open Access al Sci-Hub: la democratización del conocimiento científico. Proyecto Alterius. Recuperado de: https://goo.gl/nDSgzu.

Bates, A. (2019). Teaching in a digital age (2a ed., pp. 53-55). Pressbook. Recuperado de: https://opentextbc.ca/ teachinginadigitalage/.

Benito, D. (2019). Desarrollo de un sistema web desde el enfoque de tecnologia educativa para difundir información sobre el reino fungí [Tesis de maestría]. Universidad Autónoma del Estado de México. Recuperado de: http:/ /hdl.handle. net/20.500.11799/105220.

Benito, D., y Soberanes, A. (2019). Desarrollo de un sistema de instrucción asistida por computadora para apoyar al proceso de enseñanza aprendizaje sobre temas relacionados con hongos. Programación Matemática y Software, 11(1), 59-67.

Brooke, J. (1996). SUS: a "quick and dirty" usability scale. En P. Jordan, B. Thomas, I. McLelland y B. Weerdmeester, Usability evaluation in industry (pp. 189-194). Taylor \& Francis Ltd.
Cao, X., Wang, F., y Zheng, Z. (2012). The experimental research on eLearning instructional design model based on cognitive flexibility theory. Physics Procedia, 25(2012), 997-1005.

Corral, R. (2001). El concepto de zona de desarrollo próximo: una interpretación. Revista Cubana de Psicología, 18(1), 72-76.

David, P., y Foray, D. (2002). Una introducción a la economía y a la sociedad del saber. Revista Internacional de Ciencias Sociales, 2002(171), 7-28.

Dimuro, J. (2014). Guía de usabilidad web. Recuperado de: https://docplayer.es/6384823-Guia-de-usabilidad-web-juan-j-dimuro-2014-correccion-carolinacondado.html.

Galvis, A. (1997). Ingeniería de software educativo. Santa Fe de Bogotá, D. C., Colombia: Ediciones Uniandes.

García, J., Gargallo, B., García, A., y Sánchez, F. (2012). Sociedad del conocimiento y educación. Madrid: UNED.

Guzmán, G. (1995). La diversidad de hongos en México. Ciencias, 1995(39), 52-57.

Lozada, J. (2014). Investigación aplicada: definición, propiedad intelectual e industria. Cienciamérica, 3(1), 34-39.

Marín, S. (2012). Apropiación social del conocimiento: una nueva dimensión de los archivos. Revista Interamericana de Bibliotecología, 35(1), 55-62.

MIT [Massachusetts Institute of Technology] (2017). GSSD. Sistema global para desarrollo sustentable. Sistema de conocimiento. Recuperado de: https://goo. $\mathrm{gl} / 8 \mathrm{kfGaW}$. 
Marotias, L. (2015). Acceso abierto: un camino hacia la democratización del conocimiento cientifico. Recuperado de: https:// goo.gl/VJH8we.

Mestre, U., Fonseca, J., y Valdés, P. (2007). Entornos virtuales de enseñanza-aprendizaje (pp. 1-4). Ciudad de Las Tunas: Editorial Universitaria. Recuperado de: https://goo.gl/8xqZ2q.

Ortiz, D. (2012). La usabilidad como recurso de gestión de contenidos web: una aproximación para la optimización de portales web corporativos. Educación y Ciencia, 2012(15), 205-228.
Ortiz, D. (2015). El constructivismo como teoría y método de enseñanza. Sophia, Colección de Filosofía de la Educación, 2015(19), 93-110.

Pinto, A. (2013). Construcción colectiva de conocimiento. Envigado, Antioquia: Institución Universitaria de Envigado.

UNESCO (1984). Glossary of educational technology terms. París: Unesco.

Universidad de Granada (2017). Sistemas de conocimiento. Recuperado de: https://goo.gl/Xdriep.

Cómo citar este artículo:

Benito Moran, D., y Soberanes Martín, A. (2021). Proposal of an educational technology approach for a web system construction. Application case: teaching about the Fungi kingdom. IE Revista de Investigación Educativa de la REDIECH, 12, e1126. doi: https://doi.org/10.33010/ie_rie_rediech.v12i0.1126. 